\title{
Development of a multiparticulate system containing enteric- release mini-tablets of omeprazole
}

\author{
Volnei Jose Tondo Filho, Itamar Francisco Andreazza*, Mayumi Elisa Otsuka Sato, \\ Fábio Seigi Murakami
}

Department of Pharmacy,Federal University of Paraná, Curitiba, PR, Brazil

\begin{abstract}
The main aim of this study was to develop a multiparticulate system containing mini-tablets of omeprazole formulated with an enteric polymer with $\mathrm{pH}$-dependent solubility. Pre-formulation studies showed good flow and compaction capacity, leading to the production ofhigh quality mini-tablets. The mini-tablets were coated in a fluidized bed with hydroxypropylmethylcellulose /Eudragit ${ }^{\circledR}$ L30D55 and packed into hard gelatin capsules. The dissolution profile showed gastro-resistance and zero-order kinetics. The dissolution profile for the formulation containing lactose as the diluent and coated with $12 \%$ (tablet weight gain) of polymer was similar to that ofthe reference drug.
\end{abstract}

Uniterms: Multiparticulate system/modified release. Enteric release mini-tablets/development. Enteric release mini-tablets/evaluation. Omeprazole/dissolution.

O presente trabalho teve como objetivo desenvolver e avaliar um sistema multiparticulado de liberação modificada, composto por mini-comprimidos revestidos com polímero de liberação pH-dependente, utilizando como fármaco modelo o omeprazol. Os mini-comprimidos (diâmetro de 2,5 mm) foram obtidos em máquina de compresssão excêntrica, revestidos em leito fluidizado com hidroxipropilmetilcelulose/ Eudragit ${ }^{\mathbb{R}}$ L30D55 e, em seguida, acondicionados em cápsulas gelatinosas duras. A partir dos resultados obtidos no perfil de dissolução foi possível demonstrar a liberação gastro-resistente e comportamento cinético de ordem zero. A formulação contendo lactose como diluente, com revestimento de $12 \%$ de polímero, demonstrou semelhança com o medicamento referência.

Unitermos: Sistema multiparticulado/liberação modificada. Mini-comprimidos de liberação entérica/ desenvolvimento. Mini-comprimidos de liberação entérica/avaliação. Omeprazol/dissolução.

\section{INTRODUCTION}

The solid dosage forms of drugs for oral use are marketed all over the world and are classified according to their drug release behavior as conventional or modified release (Ashford, 2005; Allen, Popovich, Ansel, 2013)

The modified-release dosage forms are designed as monolithic or multiparticulate systems, and their function is to modify the bioavailability of the drug and extend the release or control the beginning of the drug dissolution in the gastrointestinal tract(Costa, Lobo, 1999; Lee, Robinson, 2000; ANVISA, 2010).

In a monolithic system the total administered drug is concentrated in a single release unit (tablet, coated tablet

"Correspondence: I. F. Andreazza. Departmento de Farmácia, Universidade Federal do Paraná. Av. Pref. LothárioMeissner, 632 - Jardim Botânico, 80210170 - Curitiba - PR, Brasil. E-mail: itamar@ufpr.br or hard gelatin capsule). In contrast, in multiparticulate forms the drug is divided into several functional subunits, such as granules, pellets or mini-tablets (coated or not), contained within a final dosage form (tablet or softgel) that disintegrates rapidly after administration releasing the subunits into the gastrointestinal tract. This reduces the risk of a high local drug concentration and the potential effect of localized irritation of the gastric mucosa (GhebreSellassie, Knoch, 2002; Pezzini, Silva, Ferraz, 2007).

In order to optimize the multiparticulate system, the subunits that comprise it can be coated to protect the drug, to mask the taste and/or odor, to protect against digestive fluids (enteric coating) or to control the drug release (Aulton, 2005; Pezzini, Silva, Ferraz, 2007).

Mini-tablets are tablets with a diameter equal to or less than $3 \mathrm{~mm}$, obtained in a conventional compressor machine using punches of single or multiple punch presses, with direct compression being the most suitable method, 
especially in the case of drugs with sensitivity to humidity and/or temperature, when the formulation demonstrates appropriate flow and compression properties. Other compression techniques can also be used but due to the larger numbe rof operations required these methods are not as attractive (Rouge et al., 1997; Lennartz,Mielck, 2000)

Omeprazole (OMP) is a lipophilic drug, which behaves as a weak base and it is moderately soluble in alcohol and slightly soluble in water $\left(\mathrm{pKa}_{1}=4.2\right.$ and $\mathrm{pKa}_{2}=9.0$ ). In aqueous solution at $25^{\circ} \mathrm{C}$ there is the complete formation of a precipitate at $\mathrm{pH}=2.2$ to 4.0 and at $\mathrm{pH}=11$ the drug degrades in less than 4 hours (Mathew, Gupta, Bailey, 1995; Riedel, Leopold, 2005).

In the preparation of medicinal products for oral use it is therefore important to consider using a protective layer comprised of a gastro-resistant polymer to maintain the integrity of omeprazole, thereby preserving its therapeutic activity (Bruntonet al., 2008; Nair et al., 2010).

In this context, the main objective of this study was to develop and evaluate a multiparticulate modifiedrelease system, containing mini-tablets of omeprazole coated with a polymer with $\mathrm{pH}$-dependent solubility.

\section{MATERIAL AND METHODS}

The pharmaceutical materials were kindly supplied by the pharmaceutical laboratory Prati Donaduzzi and used as received.

\section{Preparation of mini-tablets}

Two formulations were prepared (Table I). The size of the raw materials was standardized using a 40 mesh sieve and the materials were then mixed for 15 minutes in the BIN mixer at $15 \mathrm{rpm}$. The compacted bulk density of the mixtures obtained was evaluated in triplicate (SVM121 Erweka). The values obtained were used to determine the Hausner factor (HF) according to the procedure described in USP, 2010.

\section{Evaluation of mini-tablets}

\section{Hardness}

The hardness of the mini-tablets produced was determined in a TBH ERWEKA ${ }^{\circledR}$ hardness tester using 10 mini-tablets of each formulation (Farmacopéia brasileira, 2010).

\section{Friability}

A dust-free sample $(3 \mathrm{~g})$ of mini-tablets was accurately weighed and analyzed in a tablet friability
TABLE I - Formulation of mini-tablets containing omeprazole

\begin{tabular}{lcc}
\hline Raw material & Formulation A (\%) & Formulation B (\%) \\
\hline Omeprazole & 11.98 & 11.98 \\
$\begin{array}{l}\text { Microcrystalline } \\
\text { cellulose }\end{array}$ & 73.65 & - \\
$\begin{array}{l}\text { Spray-dried lactose } \\
\text { Magnesium } \\
\text { carbonate }\end{array}$ & - & 73.65 \\
$\begin{array}{l}\text { Colloidal silicon } \\
\text { dioxide }\end{array}$ & 1.20 & 1.20 \\
$\begin{array}{l}\text { Hydrogenated } \\
\text { vegetable oil }\end{array}$ & 0.6 & 0.6 \\
$\begin{array}{l}\text { Sodium starch } \\
\text { glycolate }\end{array}$ & 4.19 & 4,19 \\
$\begin{array}{l}\text { Sodium lauryl } \\
\text { sulfate }\end{array}$ & 5.99 & 5.99 \\
\hline
\end{tabular}

apparatus (Erweka ${ }^{\circledR} \mathrm{GmbH}$, Bizen, Germany) with 200 glass beads. The percentage of friability was calculated considering the initial weight (Thoma, Ziegler, 1998).

\section{Weight Variation}

Twenty mini-tablets were weighed individually in an AG200 analytical balance (Gehaka, São Paulo, Brazil) and the mean and coefficient of variation were determined.

\section{Coating of mini-tablets}

Batches of formulations A and B (mini-tablets 100g) were coated in a fluidized bed (LM-FBD 5.0/Wuster, Labmac, Sao Paulo, Brazil) with an air inlet temperature of $40^{\circ} \mathrm{C}$ and an initial flow of $2.5 \mathrm{~mL} \cdot \mathrm{min}^{-1}$ followed by $10 \mathrm{~min}$ at $4 \mathrm{~mL} \cdot \mathrm{min}^{-1}$. The insulating layer of $4 \%(\mathrm{w} / \mathrm{v})$ aqueous hydroxypropyl methylcellulose (HPMC) was applied until a weight gain of 3\% was achieved. After this treatment, the mini-tablet batches were covered with an enteric coating, employing the same equipment and conditions, using an aqueous dispersion of Eudragit ${ }^{\circledR}$ L30D55, talc, triethyl citrate and titanium dioxide, to give weight gains of 8,10 and $12 \%$. These batches were evaluated employing the dissolution test (acid phase) to determine the minimum effective coating, considering the amount of polymer that provides an OMP release of $<10 \%$.

\section{Preparation of multiparticulate dosage form}

Multiparticulate systems were prepared in hard gelatin capsules (size 3 ), encapsulating in each one around $200 \mathrm{mg}$ of mini-tablets (equivalent to $20 \mathrm{mg}$ of OMP). The samples containing uncoated mini-tablets were 
denominated as systems A and B (Table I). Also, they were referred to as 1 or 2 according to the amount of coating required to meet the minimum effective coating (10 or $12 \%$ of tablet weight, respectively).

The samples were thus named as follows: formulation A1 (with $10 \%$ of weight gain); A2 (with $12 \%$ of weight gain); formulation B1 (with $10 \%$ of weight gain) and B2 (with $12 \%$ of weight gain).

\section{Determination of omeprazole in uncoated and coated mini-tablets}

The content of OMP in the mini-tablets was determined by high performance liquid chromatography (HPLC) according to the United States Pharmacopoeia(United States, 2010).

Dissolution profile of the multiparticulate dosage forms

The reference sample (REF)and the systems A, B, $\mathrm{A} 1, \mathrm{~A} 2$, B1 and B2 were evaluated in a Varian dissolution apparatus (paddle), at a speed of $100 \mathrm{rpm}$ and temperature of $37^{\circ} \mathrm{C} \pm 0.5{ }^{\circ} \mathrm{C}$. The dissolution test was conducted at $150 \mathrm{~min}$, divided into two steps. The first step was performed in $120 \mathrm{~min}$ using $0.1 \mathrm{M}$ hydrochloric acid $(500 \mathrm{~mL})$ with a $10 \mathrm{~mL}$ sample removed at the end of the step. In the second step (30 min) $400 \mathrm{~mL}$ of $0.235 \mathrm{M}$ dibasic potassium phosphate buffer was added to the dissolution medium and the $\mathrm{pH}$ was adjusted to 6.8 . Samples $(10 \mathrm{~mL})$ were removed at 125, 130,135, 140 and 150 min after the start of the test. The dissolved drug content was evaluated by HPLC (United States Pharmacopoeia, 2010).

For the uncoated mini-tablets (A and B) the dissolution was evaluated without passing through the first step to prevent the acid decomposition of OMP. The comparison between the dissolution profiles was performed by analysis of the difference (f1)/similarity (f2) factors and the dissolution efficiency (DE). The comparison between the DE values was performed by analysis of variance (ANOVA - single factor) with a significance level of 5\% (Khan, 1975; Marcolongo, 2003).

\section{Study on OMP release kinetics}

To identify the most suitable kinetic model to describe the drug release from the multiparticulate system developed zero-order, first-order and Higuchi (or pseudozero-order)equations were used (Jug, Becirevic-Lacan, 2004).

\section{RESULTS AND DISCUSSION}

\section{Evaluation of mixtures and mini-tablets obtained}

The Hausner factor (HF) was used to predict the flow properties of the powder mixtures, since this measurement is closely related to the friction between the particles of the mixture. Both formulations showed good flow properties represented by their HF values of 1.20 (for A) and 1.17 (for B), and thus the mini-tablets (A and B) could be obtained by direct compression (Aulton, 2005).

\section{Characterization of uncoated mini-tablets}

Table II shows the results obtained for the uncoated mini-tablets (cores). The parameters were adapted to the specifications of the monograph for tablets given in the Brazilian Pharmacopoeia 2010. The hardness values of $>3.5 \mathrm{Kgf}$, the good results obtained in the friability test and the non-occurrence of capping, cracks or lamination demonstrated the mechanical strength of the cores ( $\mathrm{Wu}$ et al., 2008). The omeprazole contents were determined by HPLC and were in agreement with the compositions detailed in Table I.

\section{Minimum effective amount of enteric coating}

Batches of mini-tablets coated with appropriate amounts of polymer to give $10 \%$ and $12 \%$ weight gain were dissolved by less than $10 \%$ after a 120 -min test in acid medium, confirming the gastric resistance within the specified $\mathrm{pH}$ range.

The multiparticulate dosage forms were prepared in hard gelatin capsules with batches of mini-tablets of formulations A and B with coating levels of 10 or $12 \%$ and designated as 1 and 2 (i.e., A1, A2, B1, B2), respectively.

TABLE II - Characterization of mini-tablets produced

\begin{tabular}{lccc}
\hline Analysis & Formulation A & Formulation B & Limits \\
\hline Friability (\%) & 0.34 & 0.45 & $<1.5$ \\
Hardness (kgf) & $6.2 \pm 0.4$ & $6.3 \pm 0.3$ & $\geq 3$ \\
Mean Weight (mg) & $12.35 \pm 0.34$ & $12.40 \pm 0.36$ & - \\
Concentration (\% w/w) & $11.89 \pm 0.19$ & $11.95 \pm 0.17$ & $11.37 \leq \mathrm{R} \leq 12.57$ \\
\hline
\end{tabular}


TABLE III - Result for contents and average weight of coated mini-tablets of omeprazole

\begin{tabular}{lcccc}
\hline Analysis & A1 & A2 & B1 & B2 \\
\hline Mean Weight $(\mathrm{mg})$ & $14.18 \pm 0.42$ & $14.52 \pm 0.29$ & $14.17 \pm 0.54$ & $14.58 \pm 0.44$ \\
Concentration $(\% \mathrm{w} / \mathrm{w})$ & $10.24 \pm 0.15$ & $10.05 \pm 0.20$ & $10.29 \pm 0.14$ & $10.07 \pm 0.18$ \\
\hline
\end{tabular}

The composition of each formulation corresponds to around $200 \mathrm{mg}$ of mini-tablets(equivalent to $20 \mathrm{mg}$ of OMP)in accordance with the content of omeprazole determined by high performance liquid chromatography (HPLC) and described in Table III.

All samples evaluated presented different omeprazole contents according to their formula and this value serves as a reference for determining the level of coating required. For the coated batches, the omeprazole content decreased as the level of coating applied increased. Thus, a higher drug content indicated a lower level of coating (Amighi, Moes, 1996).

\section{Dissolution profile of the reference product}

The dissolution profile of the reference drug showed $\mathrm{pH}$-dependence, consistent with retarded drug release (Figure 1).

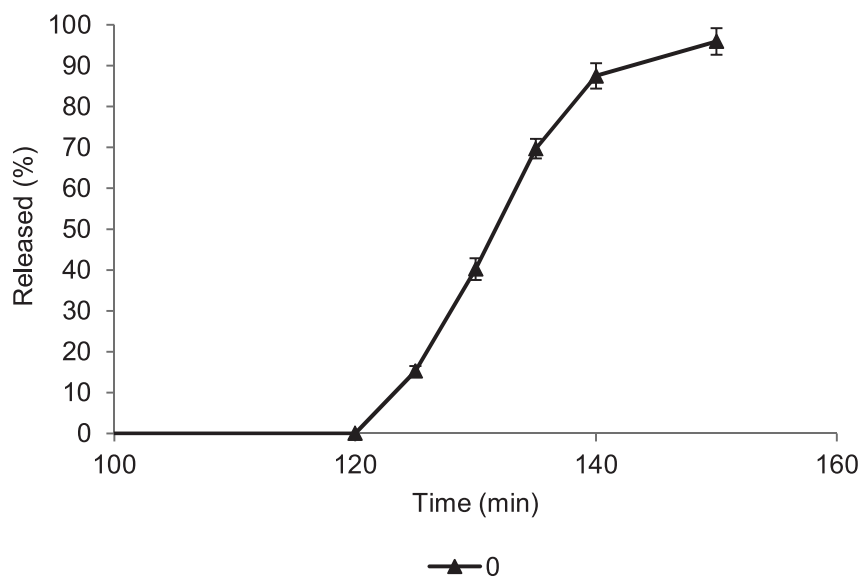

FIGURE 1 - Reference omeprazole released (\%) in the dissolution test $(\mathrm{n}=18)$.

The release of OMP from capsules containing mini-tablets is regulated by the system reservoir. After dissolution of the coating, the pharmaceutical formulation was rapidly dissolved. The typical sigmoid shape of the curve indicates that the disintegration and dissolution are comparable. The behavior under different $\mathrm{pH}$ conditions was consistent with that expected, that is, no release at pH 1.0 and rapid release in pH 6.8 (Maganti, Elik, 1994).

\section{Dissolution profile of the formulations prepared}

The encapsulated mini-tablets (A and B)showed more than $90 \%$ of drug release after 10 min of testing in phosphate buffer $\mathrm{pH} 6.8$ (Figures 2 and 3), behaving as an immediate-release dosage form. This behavior was expected, since the compositions do not include components that modify the release process.

The multiparticulate systems A1, A2, B1 and B2 (Figures 2 and 3 ) showed $\mathrm{pH}$-dependent dissolution profiles with the dissolution of the drug beginning after changing the dissolution medium to $\mathrm{pH} 6.8$ (120 $\mathrm{min})$ with the release reaching over $90 \%$ after 150 min of testing. This behavior was also expected, since the gastro-resistant polymer coating was derived from methacrylic acid (Eudragit ${ }^{\circledR}$ L30D55), which dissolves at $\mathrm{pH}>5.5$ (Chuong, Christensen, Ayres, 2008).

The dissolution of $<1 \%$ at acidic $\mathrm{pH}$ showed that the polymer coating provided good control of the drug release at the two levels of coating evaluated $(10 \%$ and $12 \%$, by weight), but the mini-tablets with a higher amount of polymer used in the coating (12\%) showed more effective control.

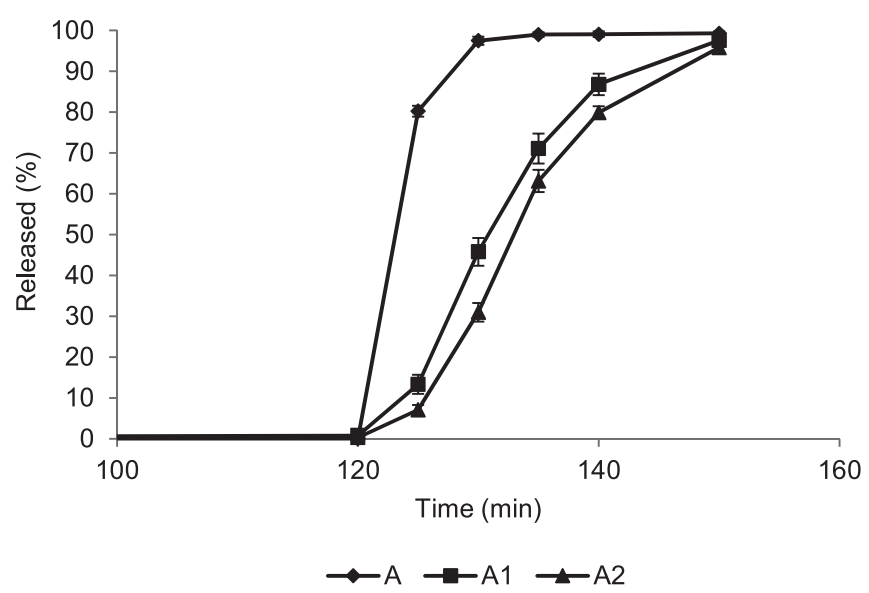

FIGURE 2 - Drug release profiles of formulations A, A1 and A2 $(n=18)$.

\section{Comparison of dissolution profiles}

A comparative evaluation of the dissolution profiles (Figure 1, 2 and 3) is useful in the selection of formulations 


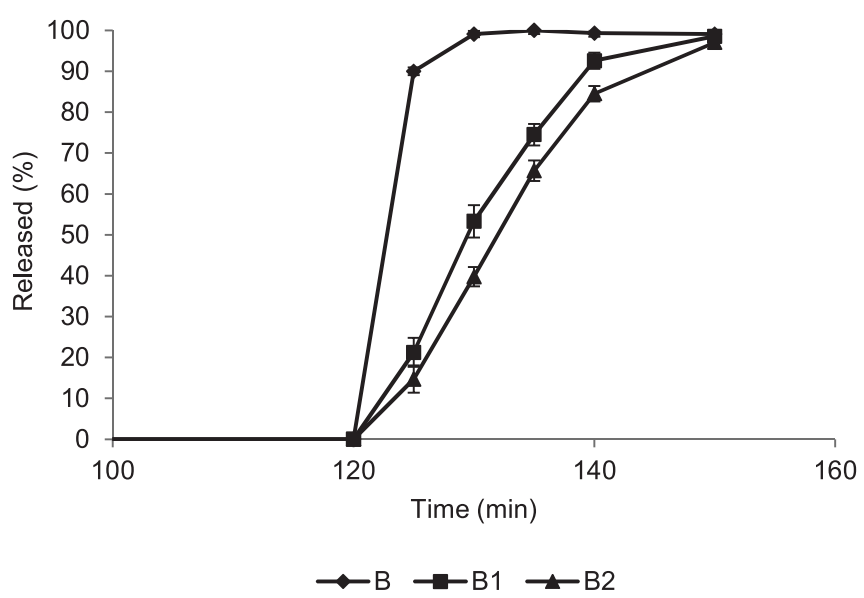

FIGURE 3 - Drug release profiles of formulations B, B1 and $\mathrm{B} 2(\mathrm{n}=18)$.

during the processes related to pharmaceutics and also to establish the similarity between a new general formula and its reference (Moore, Flanner, 1996; Adams et al., 2001).

A comparison of the dissolution profiles using the factors f1 and f2 (Table IV) demonstrated that all formulations had dissolution profiles similar to that of the reference drug (ANVISA, 2010).

The dissolution efficiency (DE\%; Table IV) is an important parameter of the release kinetics and it allows the comparison of two formulations (Costa, Lobo, 1999). For a more detailed assessment, the dissolution study was accompanied by statistical analysis to infer the similarity between the dissolution profiles obtained. The analysis of variance (ANOVA) results showed that only the capsule containing B2 mini-tablets (Table V) showed a DE\% similar to the reference drug. However, assessment of the formulation by determining the $\mathrm{DE} \%$ is not addressed by pharmaceutical regulatory agencies.

TABLE IV - Results for $\mathrm{f} 1, \mathrm{f} 2$ and DE\% of capsules containing coated mini-tablets

\begin{tabular}{lccc}
\hline Samples & f1 & f2 & DE (\%) \\
\hline Reference & & & $56.73 \pm 3.44$ \\
A1 & 3.63 & 76.20 & $59.66 \pm 0.74$ \\
A2 & 10.25 & 57.21 & $52.83 \pm 0.67$ \\
B1 & 10.22 & 56.29 & $64.41 \pm 1.15$ \\
B2 & 2.96 & 79.83 & $57.3 \pm 1.00$ \\
\hline
\end{tabular}

The results revealed that the different methods used to compare dissolution profiles can lead to antagonistic results. However, the application of these methods can provide more accurate information on the dissolution behavior of products, facilitating the development or optimization of formulations.

TABLE V - Dissolution efficiency (\%) in comparison with reference using ANOVA

\begin{tabular}{lccc}
\hline & $\mathbf{F}_{\text {calculated }}$ & $\mathbf{F}$ & Results \\
\hline A1 & 5.5421 & 4.6001 & Different \\
A2 & 9.8165 & & Different \\
B1 & 35.81 & & Different \\
B2 & 0.2229 & & Similar \\
\hline
\end{tabular}

The quantitative interpretation of the values obtained for the dissolution profiles, based on the percentage dissolved versus time, is facilitated by the use of mathematical models (Marcolongo, 2003; Kumar, Tewari, 2006).

In this study, three mathematical models were applied for the interpretation of the dissolution kinetics: zero-order, first-order and the Higuchi model. The kinetics models were evaluated through the linearization of the profile data according to the dissolution time and percent drug released. To select the most suitable model the coefficient of correlation ( $r$ ) is calculated, to identify which model most closely approaches perfect linearity. The results for the linearization of the data are shown in Table VI.

TABLE VI - Study on release kinetics

\begin{tabular}{lccc}
\hline Formulation & Zero-order & First-order & Higuchi \\
\hline A1 & 0.9218 & $\mathbf{0 . 9 5 8 4}$ & 0.9154 \\
A2 & $\mathbf{0 . 9 4 6 5}$ & 0.9391 & 0.8711 \\
B1 & 0.9005 & $\mathbf{0 . 9 6 1 1}$ & 0.9409 \\
B2 & $\mathbf{0 . 9 4 6 5}$ & 0.9458 & 0.9170 \\
Reference & 0.9246 & $\mathbf{0 . 9 6 5 7}$ & 0.9109 \\
\hline
\end{tabular}

The correlation coefficients for the formulations showed different release kinetics. The A2 and B2 minitablets presented zero-order release kinetics profiles, indicating that the release occurs independently of the amount of drug remaining, due to excess coating being employed, which delayed the early release.

The formulations A1 and B1 showed first-order release kinetics, where the amount of drug released versus time is dependent on the amount of drug remaining in the formulation, this being the model that best fits the immediate-release formulations, in agreement with descriptions in the literature (Cid, 1981). 


\section{CONCLUSIONS}

The mini-tablets containing omeprazole prepared by direct compression presented smooth edges and uniform color and were able to support the coating processes. Coating of the mini-tablets with $10 \%$ (in terms of weight gain) of methacrylic polymer was sufficient to obtain the desired gastro-resistance.

The proposed formulations showed good flow properties (Hausner factor) for formulations A and B, respectively. The produced uncoated mini-tablets meet the requirement for specifications of the monograph for tablets given in the Brazilian Pharmacopoeia (2010).

The dissolution profiles of the tablets produced indicated good control of the release of the drug by the polymer coating at the two levels evaluated, indicating that the methacrylic derivative used is suitable for obtaining delayed-release systems. For the comparative analysis of the dissolution profiles based onf1 and $\mathrm{f} 2$, all capsules produced showed similarity to the reference product. Only capsules containing the mini-tablets B2 showed dissolution profiles similar to the reference drug, according to single factor ANOVA.

The first-order kinetics model was found to be most suitable to represent the release profiles of omeprazole multiparticulate systems A1 and B1 and the reference drug whereas the zero-order model was best suited for systems A2 and B2.

\section{REFERENCES}

AMIGHI, K.; MÖES, A. Influence of plasticizer concentration and storage conditions on the drug release rate from eudragit ${ }^{\circledR}$ RS30D film-coated sustained-release teophylline pellets. Eur. J. Pharm. Biopharm., v.42, p.29-35, 1996.

ADAMS, E.; COOMANS, D.; SMEYERS-VERBEKE, J.; MASSART, D.L. Application oflinear mixed effects models to the evaluation of dissolution profiles. Int. J.Pharm., v.226, p.107-125, 2001.

ALLEN JR, L.V.; POPOVICH, N.G.; ANSEL, H.C. Formas farmacêuticas e sistema de liberação de fármacos. 9. ed. Artmed, 2013.p.187-206.

ASHFORD, M. Biodisponibilidade - fatores físico-químicos e relacionados à formafarmacêutica. In: AULTON, M.E., (Ed.). Delineamento de formas farmacêuticas. 2. ed. Porto Alegre: Artmed, 2005. chap.17, p.245-263.
AULTON, M.E. Pharmaceutics. The science of dosage form.2ed. Edinburgh:Churchill - Livingstone, 2005.679 p.

AGÊNCIA NACIONAL DE VIGILÂNCIA SANITÁRIA. ANVISA. Resolução da diretoria colegiada $n^{\circ} 31$, de 11 de agosto de 2010. Determina a publicação do "Guia para realização dos Estudos de Equivalência Farmacêutica e de Perfil de Dissolução Comparativo". Diário Oficial da União, 2010. Available at: http://www.brasilsus.com.br/ legislacoes/rdc/105005-31.html. Accessed on May 2014.

BRUNTON, L.; PARKER, K.; BLUMENTHAL, D.; BUXTON, I. Goodman and Gilman's manual of pharmacology and therapeutics.1ed. New York: McGraw Hill, 2008.623 p.

CID, E.C. Cinética de dissolución de medicamentos. Washington: Organización de los Estados Americanos, 1981. p.102.

CHUONG, M.C.; CHRISTENSEN, J.M.; AYRES, J.W. New dissolution method for mesalamine tablets and capsules. Dissolut. Technol., v.15, p.7-14, 2008.

COSTA, P., LOBO, J.M.S. Formas farmacêuticas de liberação modificada. Rev. Port. Farm., v.59, p.181-190, 1999.

GHEBRE-SELLASIE, I.; KNOCH, A. Encyclopedia of pharmaceutical technology. 2. ed. Marcel Dekker, v.3, 2002. p.1-13.

FARMACOPÉIA BRASILEIRA. 5. ed. Rio de Janeiro: Fiocruz, 2010. p.62.

JUG, M.; BECIREVIC-LACAN, M. Influence of hydroxypropylbeta-cyclodextrin complexation on piroxicam release from buccoadhesive tablets. Eur. J. Pharm. Sci., v.21, p.251-260, 2004.

KHAN, K.A. The concept of dissolution efficiency. J. Pharm. Pharmacol., v.28, p.48-49, 1975.

LENNARTZ, P.; MIELCK, J.B. Minitabletting: improving the compactibility of paracetamol powder mixtures. Int. J. Pharm., v.173, p.75-85, 2000.

LEE, T.W.; ROBINSON, J.R. Controlled-release drug delivery systems. In: GENARO, A.R. (Ed.). Remington: the science and practice of pharmacy. 20ed. Baltimore: Lippincott Williams \& Wilkins, 2000. chap.47, p.903-929.

MAGANTI, L.; ELIK, M.C. Compaction studies on pellets: II. Coated pellets. Int. J. Pharm., v.103, p.55-67, 1994. 
MARCOLONGO, R. Dissolução de medicamentos: fundamentos, aplicações, aspectos regulatórios e perspectivas na área farmacêutica. São Paulo, 2003.114 p. [Dissertion of master degree, Faculty of Pharmaceutical Sciences, University ofSão Paulo].

MATHEW, M.; GUPTA, V.D.; BAILEY, R.E. Stability of omeprazole solutions at various $\mathrm{pH}$ values as determined by high-performance liquid chromatography. Drug Dev.Ind. Pharm., v.21, p.965-971,1995.

MOORE, J.W.; FLANNER, H.H. Mathematical comparison of dissolution profiles. Pharm. Technol., v.20, p.64-74, 1996.

NAIR, B.A; GUPTA, R.; KUMRIA, R.; JACOB, S.; ATTIMARAD, M. Formulation and evaluation of enteric coated tablets of proton pump inhibitor. J. Basic Clin. Pharm., v.1, p.215-221, 2010.

PEZZINI, B.R.; SILVA, M.A.S.; FERRAZ, H.G. Formas farmacêuticas sólidas orais de liberação prolongada: sistemas monolíticos e multiparticulados. Braz. J. Pharm. Sci., v.43,p.491-502, 2007.

RIEDEL, A.; LEOPOLD, C.S. Degradation of omeprazole induced by enteric polymer solutions and aqueous dispersions: HPLC investigations. Drug Dev.Ind. Pharm.,v.31, p.149-158, 2005.
ROUGE, N.; COLE, E.T.; DOELKER, E.; BURI, P. Screening of potentially floating excipients for minitablets. . STP Pharma. v. 7:p.386-92, 1997

THOMA, K.; ZIEGLER, I. Investigations on the influence of the type of extruder for pelletization by extrusionspheronization. II. Sphere characteristics. Drug Dev. Ind. Pharm., v.24, p.413-422, 1998.

TROY, D. B.; BERINGER, P. Dissolution. In: KUMAR, V.; TEWARI, D. Remington: The Science and Practice of Pharmacy. 21. ed. Baltimore: Lippincott Williams \& Wilkins, 2006. p.672-688.

UNITED STATES PHARMACOPOEIA. 33. ed. Rockville: United States Pharmacopoeial Convention, 2010. p.247984.

WU, C.Y.; HANCOCK, B.C.; MILLS, A.; BENTHAM, A.C.; BEST, S.M.; ELLIOTT, J.A. Numerical and experimental investigation of capping mechanisms during pharmaceutical tablet compaction. Powder Technol., v.181, p.121-129, 2008.

Received for publication on $05^{\text {th }}$ April 2013 Accepted for publication on $20^{\text {th }}$ January 2014 
